\title{
Impact and Dilemma: New Christian Right in America
}

\author{
Huiling Zhang1* ${ }^{*}$ Anneng Deng2 \\ ${ }^{1}$ Social Science Institute, Shanghai University of Engineering Science, Shanghai, China \\ ${ }^{2}$ Institute of Marxism, East China Normal University, Shanghai, China \\ Email: *zhanghuiling2005@sina.com
}

Received 16 December 2015; accepted 23 January 2016; published 26 January 2016

Copyright (C) 2016 by authors and Scientific Research Publishing Inc.

This work is licensed under the Creative Commons Attribution International License (CC BY). http://creativecommons.org/licenses/by/4.0/

c) (i) Open Access

\begin{abstract}
New Christian Right (NCR) in America developed during the social ferment and upheaval of the 1970s, initially focusing exclusively on social issues such as abortion, gay rights, and school prayer, etc. which was a reaction to the moral decline in American society. In the 1990s, NCR adjusted their political style in addressing social problems, abandoning extreme positions and adopting mainstream politics. NCR was active in the country's national political arena, aligned with the Republican Party and gained its political fortune. The purpose of involvement in politics was to apply traditional Christian values to American public policies, but in most cases because of the challenges from both inside and outside, NCR movement had to accept compromise in order to get incremental policy gains. Unless NCR attained its final aims, it was for sure that the movement would always be around in the American political arena. NCR made a valuable topic for academic research.
\end{abstract}

\section{Keywords}

NCR, America Politics, Impact, Dilemma

\section{Introduction}

New Christian Right (NCR), composed of Christian conservative and holding orthodoxy theological and political views, is willing to be involved in American politics. The primary constituency of NCR movement is white evangelicals Protestants, but it also draws support from politically conservative Catholics, Jews, and occasionally secularists. First dissatisfied with the eclipse of traditional religious values and morality, NCR appears to be social problem muckrakers, initially focusing on social issues exclusively, such as abortion, gay rights, and school prayer, etc. But the second generation of NCR leaders decided that they would play political games according to political rules because they were impatient with limited gains achieved during the 1980s. Indeed, po-

\footnotetext{
*Corresponding author.
} 
litical pragmatism and improved tactics help the movement to accomplish unprecedented policy gains. However, New Christian Right in America faces with dilemma even though the movement itself impacts on American Politics so much.

\section{Rise and Development}

NCR developed during the social ferment and upheaval of the 1970s. Often described as pro-family, NCR in its initial period was socially conservative and was particularly concerned with such issues as abortion, homosexuality, school prayer, and pornography. Moral Majority, which was founded by Jerry Falwell, was the most influential organization in the movement at that time. From the beginning, NCR movement has been aligned with the Republican Party and it gained its first political fortune by lending its whole-hearted support to Ronald Reagan when he was bidding for presidency in 1980. In the 1980 elections, the evangelicals formed a powerful electoral constituency, claiming credit for the victories of a Republican President and a Republican control of the Senate (first time in over 20 years). The elected President pledged to work for enactment of the agenda of the NCR, so standing by the side of President Reagan, NCR rose to national prominence suddenly. Though clamorous at the surface, the movement achieved few actual policy accomplishments during Reagan's presidency. Reagan's commitment to NCR primarily stayed at the level of lip support.

After Reagan's presidency, NCR movement went through a series of bad lucks and disorders. Under such circumstances, moral majority, central group in the movement, was formally dissolved. The movement seemed, as conventional wisdom held, to be a meteor that would "streak cross our skies" and then fall to earth "cold and exhausted" [1]. In the 1990s, NCR adjusted their political style in addressing social problems. Ralph Reed, Executive Director of the Christian Coalition (CC), is the most prominent leader in the 1990s and his organization even gained the reputation of "the Republican Party's No.1 interest group” [2]. Ralph Reed insisted that NCR should be willing to compromise to retain its political relevance. Keeping that place needs abandoning extreme positions and adopting mainstream politics. So Christian conservative activists in the 1990s improved their political tactics by adopting political pragmatism and incrementalism, meanwhile, while attention are focused on Capitol Hill, NCR put more emphasis on building local power centers and then has a stunning control of the local power centers.

\section{Impact on American Politics and Public Policies}

\subsection{American Politics}

Since the 1990s, NCR has been active in the country's national political arena. The ability to mobilize the electorate rapidly, coupled with an effective lobbying apparatus, has endowed NCR with a level of influence that is unique in American politics. "A lot of groups have a great Washington presence and some have great grassroots", observed one Congressman, "but few combine them both (as the CC does)" [3].

Lobbying for Influence: NCR leaders do not like the term lobbying, nevertheless, NCR groups take this old trick as the focus of their political efforts in Washington DC. Effective advocacy is and has always been a combination of outside pressure and inside influence coalescing in favorable circumstances. In the respect of outside pressure, NCR groups are highly successful because of their large-numbered mass supporters who can effectively bring pressure to bear on members of Congress and other officials. The threat of electoral defeat remains a powerful motivator for modern politicians and groups with many members or well-heeled contributors can make a difference in a politician's fortunes on the election day. Mass mobilization, or grassroots mobilization, is the technique commonly used by NCR groups. Television and radio ministry connections, computer lists of contributors, affiliated churches can generate a sea of letters or phone calls to elected officials. With advanced communication technology, Internet has also been used to generate grassroots response. A variety of NCR groups now support web sites that allow supporters to send e-mails about issues of concern directly to Congress.

In some cases, the mass mobilization is supplemented by the so-called elite mobilization, that is, to court the support of the influential community leaders and party contributors. Usually, NCR organizations have a name list of the high-level supporters. When occasion arises, the elites will be immediately contacted. Sometimes a few influential figures can have greater clout than a million relatively unsophisticated supporters or newcomers to politics. However, no matter how much outside pressure can be mounted, it can mean little without skillful inside lobbying. Inside lobbying, or direct lobbying, involves personal encounters between lobbyists and public 
officials. It often takes the form of personal contact and testimony at hearings, etc. The combination of outside and inside lobbying activities produces effectiveness. Outside lobbying, such as grassroots mobilization and mass media propaganda, moulds the public opinion on certain issues, thus creating a favorable environment for inside activities. Via skilled lobbyists, the public voice is delivered directly to legislators and other officials. Outside pressure and inside influence work supplementarily to influence the policy makers' position.

Involvement in National Elections: For interest groups, an effective way to exert political influence is to get involved in political elections and campaigns. Since the 1990s, NCR has proved themselves to be an important force in the wining coalition of the GOP (Grand Old Party, that is, the Republican Party). The phenomenon that the white evangelicals form a powerful voting bloc in GOP is of recent vintage. In the 1960s, the Protestant mainline was a major voting bloc and the core of the Republican coalition. In contrast, evangelicals were barely recognized as a separate religious tradition, let alone an electoral constituency. The turning point came with the 1980 Presidential election. The victory of Ronald Reagan called the public attention to evangelicals. Since then, white evangelicals have become more and more aligned with the Republican Party, gradually replacing the historical position of mainline Protestants [4].

Influence in the Judicial Branch: In order to be truly influential in American politics, interest groups must be participants in every major playing field, including not only legislative and executive branch, but also the courts. Legal decisions made by state and federal courts have an enormous influence on NCR's policy achievements. Without judicial support, success in legislative or executive branches may end up in vain. Another strategy in judicial politics is to influence the judicial selection process. The significance of this approach is obvious, for putting like-minded persons into the judicial branch helps to ensure favorable court decisions. And it can be predicted that NCR will try to help more of their persons into the judicial institutions in the future.

\subsection{Public Policies}

The purpose of NCR's involvement in politics is to apply traditional Christian values to American public policies. NCR's traditional agenda aims at restoring family values and that is why it has also labeled itself as "pro-family" movement. They were concerned overwhelmingly with social problems which involve moral disputes, such as abortion, homosexuality, school prayer etc. NCR's "pro-family" agenda is a reaction to the moral decline in American society, which, in their view, was caused by the wide spreading of liberal ideology. In the 1990s, in order to broaden its appeal to average Americans, the movement has expanded their agenda to include some conservative economic issues, education issues, budget, and foreign matters as well.

Abortion: When it comes to the issue of abortion itself, the religious conservatives does not demand a constitutional amendment banning abortion —or even hearings on such a measure. Instead, they have pressed for votes to end only partial-birth, or late-term abortion, which is dubbed as new strategies for protecting the unborn. By shifting the emphasis from prohibiting abortion to restricting it, the Christian conservatives attempt to reframe the political debate on abortion in ways that maintain enthusiasm among "right-to-life" voters while developing non-threatening, middle-ground positions that can appeal to most Americans. The new strategy has worked.

While a constitutional amendment banning abortion is unlikely, many other attempts are also made to curtail it. One target is Medicaid, for it involves the funding of abortion. Now it funds abortion only in cases of rape, incest and the life of the mother. Other ideas include weakening a law making it a crime to block access to abortion clinics and reimposing a rule that bars family planning clinics receiving federal funds from counseling patients about abortion. Positions on the issue of abortion can also change the lot of local politicians, but in this respect, NCR does not require their favorite candidate to take extremely conservative stance.

One thing that should be made clear is that while the conservative religious leaders have adopted the incremental strategy, their ultimate goal remains unchanged - the legal protection of life. Their compromise on abortion issue comes as a result of full realization of the immature timing for the time being. Just as Dobson said: "There won't be a ban until the American people are ready to accept it" [5]. The Christian conservatives are putting the abortion issue on the road of "ultimate extinction".

Homosexuality: The antigay agenda was born in the 1970s, shared the stage with other NCR's preoccupations in the 1980s, and rose to prominence again in the 1990s. In NCR's view, homosexuality is disgusting, evil, and extremely dangerous. During the 1990s, NCR's vilification of homosexuals reached an all-time high.

Religious Liberty: The First Amendment to the American Constitution addresses the relation between religion and politics, that is, Congress shall make no law respecting an establishment of religion, or prohibiting the 
free exercise thereof. This provision, which is open to different interpretations, is highly controversial within the US. NCR disapprove a total separation between church and state in the United States. Religious liberty controversies intensively arise in the public schools.

Ever-prepared for opportunities to fight for a higher degree of religious freedom, NCR organizations and their political allies have used the period of mourning and reflection that followed the September 11 terrorist attacks to promote their long-held agenda. It is observed that after the surprise attack, there is more religious expression going on in public schools than at any time in history. Across the country, NCR has seized the opportunity to push for organized, state-sponsored prayer in public schools. Another development after Sept. 11 is the growing interest in posting the national motto "In God We Trust" in public schools. Bible studies in public schools also attract attention across the country.

NCR's traditional pro-family agenda includes primarily moral issues such as abortion, homosexuality, and school prayer, while the broadened agenda contains "pocketbook" issues which speak to the concerns of people's everyday life, such as Tax Cut, Health Care, Education, etc. Noticeably, the expanded agenda contains not only some of the domestic issues but also foreign matters as well. In foreign policy field, the motivation of NCR's involvement primarily derives from the movement's traditional concern, such as anti-abortion and upholding religious freedom. How to evaluate NCR's influence on U.S. public policy? There is no denying that the movement is now more powerful than it was in the past, but it is still hard to measure exactly how powerful it is. From the analysis above, it is evident that NCR is still far from achieving its ultimate goals. Unless NCR attains its final aims, it is for sure that the movement will always be around in the American political arena.

\section{Dilemma}

NCR movement has a grand plan to drastically change some of America's domestic and foreign policies and they have achieved a lot, but they are still far from achieving their ultimate goals. NCR cannot exert its utmost political influence because of the following besetting factors.

Since the 1990s, NCR movement has succeeded in gaining greater political influence because NCR leaders in the 1990s have abandoned the "purist" strategy of the past and have developed new organizations with tactical and ideological improvement. But at the same time it is facing an unprecedented internal crisis. Not all in the movement welcome political pragmatism, thus a conflict is inevitable. Ralph Reed argued for a pragmatic approach to politics, criticizing "purists" for their exclusionary language, inflammatory rhetoric on the social issues, and immutable goals in the face of certain defeat, while many other activists within the movement have been expressing disappointment with Reed and others who preach pragmatism. With such internal split, NCR can hardly speak with one voice. It seems to be an unsolvable problem for NCR movement: to take a pragmatic approach - thereby risk losing the movement's core constituency and financial resources; to follow a more ideological course-but fail to achieve a majority and to acquire political influence. For any religious movement, such dilemma is inevitable.

From the beginning, NCR has been subject to criticism and hostility from the liberal world. The liberal groups have waged war against NCR in nearly every field of its activity. In the multicultural society of the US, the movement falls short of the "moral majority" it often portrays itself as. Many Americans accept the "Trojan horse" interpretation of NCR because they are suspicious of the movement's ambition. The real aim of NCR, according to this interpretation, is to impose evangelical religion and morality on American society, to destroy the constitutional principle of "separation of church and state", and finally, to establish a totalitarian theocracy—a Christian fundamentalist version of Iran [6]. A book called Holy Terror describes the evangelicals as the "Holy Terror" and warns that "a guerrilla war on our private thoughts, feelings, and beliefs, on our nation's timeless values and historic freedoms, [is] being waged". A New York Times ad claimed, "The new evangelicals are a radical anti-Bill-of-Rights movement. They seek not to conserve traditional American values, but to overthrow them" [7].

A polling shows that while 40 percent of Americans express concern about Democrats' ties to radical liberal groups, 39 percent are worried by Republican ties "to conservative special interests like the religious right and the moral majority" [2]. In order to please its conservative core supporters, the Republican Party has been facing the danger of driving away its moderate followers. That situation has appalled moderates within the party. NCR will never achieve consensus within the Republican Party.

In most cases, NCR movement has to accept compromise in order to get incremental policy gains. In this 
sense, NCR movement cannot be reckoned as one of the deciding forces in US policy-making process. If New Christian Right wants to achieve its goals, there's still a long way to go for NCR in America politics.

\section{Conclusion}

NCR makes a valuable topic for academic research because of being persistent and powerful in American political arena. NCR is willing to accept compromises to get incremental gains because of having sensed the impossibility of attaining its ultimate policy goals. The purpose in doing so is to remain vigorous on the political stage and to prepare for fighting for future success when the right time comes. An appropriate evaluation of NCR should be such: a powerful but not deciding force in American policy-making process.

\section{References}

[1] Lienesch, M. (1993) Redeeming America: Piety and Politics in the New Christian Right. University of North Carolina Press, London, 1.

[2] Roberts, S.V., et al. (1995) Church Meets State. U.S. News \& World Report, 26.

[3] Martin, W. (1999) The Christian Right and American Foreign Policy. Foreign Policy, No. 114, 69-80. http://dx.doi.org/10.2307/1149591

[4] Kellstedt, L.A., Green, J.C., Guth, J.L. and Smidt, C.E. (1994) Religious Voting Blocs in the 1992 Election: The Year of Evangelical? Sociology of Religion, 55, 307-326. http://dx.doi.org/10.2307/3712056

[5] Gerson, M.J. (1998) For Key Abortion Foes, a Sudden Pragmatism. U.S. News \& World Report, 25.

[6] Watson, J. (1997) The Christian Coalition: Dreams of Restoration, Demands for Recognition. St. Martin’s Press, New York, 176-178.

[7] Smith, C. (2000) Christian America? What Evangelicals Really Want? University of California Press, Berkeley, 92. 